\title{
PARATOPIA E VIOLÊNCIA SEXUAL NO DISCURSO DE DALTON TREVISAN
}

\author{
Renan Gonçalves Locatelli (PUC-SP)
}

A presente pesquisa inscreve-se na Análise do Discurso de orientação francesa e, por esta razão, partilha de seus pressupostos teórico-metodológicos, pautando-se, sobretudo, nos trabalhos de Maingueneau (2016, 2015, 2010 e 2008) com o objetivo de investigar o papel da paratopia no discurso de Dalton Trevisan e analisar as estratégias discursivas presentes em $O$ Vampiro de Curitiba, obra cuja temática circunscreve-se em tomo da violência sexual. Trata-se de um tema relevante, dado que a paratopia concernente ao discurso literário, assim como o discurso da violência sexual, são explorados de maneira incipiente no âmbito acadêmico. Parte-se do pressuposto de que o discurso literário de Dalton Transivan, ao tratar da violência sexual, constitui-se como paratopico, uma vez que encontra-se, no interdiscurso, imerso em uma dinâmica de equilíbrio instável, em concorrência com posicionamentos centrais e periféricos de outros discursos instituídos socialmente, que traçam as fronteiras entre a integração e a marginalidade no que diz respeito à temática em questão. Diante de uma posição insustentável, de pertencimento parasitário, negociando o lugar e o não lugar no campo social, a figura do vampiro - nem vivo, nem morto alude metaforicamente ao paradoxo de ordem espacial em que se encontra o discurso de Dalton Trevisan: entre desigualdades fundamentais situa-se uma gama de personagens regidas pela antologia do sexo como forma de abuso, de anulação do outro por diferentes tipos de violação da subjetividade, como a criança que é forçada ao sexo precocemente, a professora que seduz o aluno e o pervertido que coage a moça ao sadismo, revelando a face humana em estado bruto, nos limites com a civilização e, portanto, com a linguagem e a cultura.

Palavras-chave: Análise do Discurso; Paratopia; Discurso da Violência. 